\title{
An association between Wernicke's encephalopathy and thyrotoxicosis
}

\author{
B. A. ENOCH \\ B.Sc., M.B. \\ Registrar in Medicine, \\ Department of Medicine, \\ Royal Hospital, Sheffield 1
}

\author{
D. M. Williams \\ M.B., B.Ch. \\ Senior House Officer, \\ Medical Unit, \\ Cardiff Royal Infirmary
}

THE SYNDROME bearing Wernicke's name was first documented by Gayet (1875). Wernicke (1881) described three cases, two occurring in chronic alcoholics, the other following sulphuric acid poisoning. Wechsler (1932) appears to be the first person to associate this encephalopathy with a vitamin deficiency. Jolliffe, Wortis \& Fein (1941) and Campbell \& Russell (1941) have described many cases, the majority occurring in alcoholics.

The disorders which have been associated with Wernicke's encephalopathy are chronic alcoholism, carcinoma of the stomach, gastritis, pyloric stenosis, chronic dyspepsia, peritonitis, hyperemesis gravidarum, pernicious anaemia, syphilis and bronchiectasis (Campbell \& Russell, 1941).

This report describes the previously unrecorded association between Wernicke's encephalopathy and thyrotoxicosis.

\section{Case history}

The patient, a female aged 61 years, worked in a sparking-plug factory in South Wales. She lived with her two daughters and ate a normal diet. She was perfectly well until December 1965 but then developed anorexia and over an 8week period up to the end of January 1966 lost 2 stones in weight. There was no history of alcoholism. She returned home from work one day complaining of giddiness, bilious vomiting and severe retching; these symptoms persisted for 2 weeks and she was admitted to hospital for investigation. Apart from weight loss, nothing abnormal was found on clinical examination. A provisional diagnosis of carcinoma of the stomach was made in view of the history but barium meal was normal: a cholecystogram was also normal. No cause for the symptoms was found and she was discharged.

In early March 1966, the patient's speech became slurred. On 26 March she was fully con- scious but $48 \mathrm{hr}$ later she became stuporous and was admitted to hospital.

On examination: BP $120 / 80 \mathrm{mmHg}$, pulse 132 / min, regular. She was reacting violently to stimulation. There was evidence of weight loss, slight neck stiffness, a positive Kernig's sign, small equal pupils reacting to light and normal fundi. She had bilateral ptosis, impairement of ocular movements and sluggish tendon reflexes. A diagnosis of Wernicke's encephalopathy was made and she was transferred to St David's Hospital, Cardiff, where her mental state recovered rapidly following treatment with intravenous thiamine. However, she continued to lose weight, she developed diarrhoea, passing six motions per day, and she developed uncontrolled atrial fibrillation which was controlled successfully with digoxin. It was on account of the weight loss and diarrhoea that she was transferred to the Medical Unit at the Cardiff Royal Infirmary for investigation of probable malabsorption. On examination she was found to have generalized pigmentation and smooth skin. The hair on the head was fine; the axillary and pubic hair thin and sparse. There was slight unilateral proptosis and lid lag, but no goitre was palpable. There was evidence of considerable weight loss. The BP was $120 / 75$, pulse $120 / \mathrm{min}$, regular. (She had now reverted to sinus rhythm.) The clinical diagnosis of thyrotoxicosis was subsequently confirmed (vide infra).

Investigations: $\mathrm{Hb}, 71 \%(10.5 \mathrm{~g} / 100 \mathrm{ml}$; ESR, $17 \mathrm{~mm} / \mathrm{hr}$ (Westergren); MCHC, 30\% ; plasma electrolytes and urea, normal ; SGPT, 35 units ; SGOT, 50 units; total serum protein, $5.5 \mathrm{~g} / 100$ $\mathrm{ml}$; serum albumin, $3.1 \mathrm{~g} / 100 \mathrm{ml}$; serum bilirubin, $0.4 \mathrm{mg} / 100 \mathrm{ml}$; thymol turbidity, 2 units ; alkaline phosphatase, 5.6 K.A. units; bromsulphthalein retention test, normal; serum $\mathbf{B}_{12}$, $337 \mathrm{pg} / \mathrm{ml}$; serum folate, $4 \mathrm{ng} / \mathrm{ml}$; faeces for occult blood, negative on three occasions; lumbar puncture: CSF pressure, protein and cells, 
normal; xylose tolerance test: 21 April 1966, $0.5 \mathrm{~g} / 5 \mathrm{hr}$ specimen ( $25 \mathrm{~g}$ loading dose), 12 May 1966, 0.032 $\mathrm{g} / 5 \mathrm{hr}$ specimen (5 g loading dose); faecal fat excretion (on ward diet): 6.4, 5.4, $4.6,2.1$ and $1.3 \mathrm{~g}$, on five successive days; serum calcium, 9.3 and $8.9 \mathrm{mg} / 100 \mathrm{ml}$; W.R., negative; barium meal and follow through, normal; barium enema, normal; X-ray of thoracic inlet, no goitre; oral glucose tolerance test showed a low fasting blood sugar $(54 \mathrm{mg} / 100$ $\mathrm{ml}$ ) and a flat curve; no abnormal porphyrins were detected in the urine or faeces; fasting blood pyruvate on two occasions was abnormal: $2.5 \mathrm{mg} / 100 \mathrm{ml}$ and $2.9 \mathrm{mg} / 100 \mathrm{ml}$ (normal $0.5-1.0 \mathrm{mg} / 100 \mathrm{ml}$ )-this was prior to treatment with thiamine; EEG showed $\alpha$ waves 9-10 cycles/sec, low voltage $\beta$ waves $16-24$ cycles/ sec, high voltage slow $\theta$ and $\delta$ waves in alternate leads compatible with a biochemical encephalopathy; BMR, $+39 \% ;{ }^{131}$ I uptake: 24 hr, $78 \%, 48 \mathrm{hr}, 70 \%$; PB ${ }^{131} \mathrm{I}, 1.3 \%$ of the dose $(5 \mu \mathrm{Ci}) /$ litre of plasma. Thyroid and gastric antibodies were not detected in the serum. The patient was treated with carbimazole $10 \mathrm{mg}$ t.d.s. and was discharged home.

\section{Progress}

She has been followed up in the out-patient department, the last time being 24 July 1967 . It is now clear that her lowest weight was 5 st $8 \mathrm{lb}$ just after her transfer to the Cardiff Royal Infirmary, and after treatment with carbimazole the diarrhoea disappeared, she gained weight and improved generally. Within a month, however, she developed a goitre which subsided following thyroxine therapy. She now weighs 9 st $9 \mathrm{lb}$, the pulse is still regular and apart from a small goitre there are no abnormal physical findings. She now admits to amnesia for the period February to mid-April 1966.

\section{Discussion}

It is likely that the initial disorder in this patient was thyrotoxicosis in view of: (a) high ${ }^{131}$ I uptake, (b) PB $^{131}$ I, (c) high BMR, and (d) the clinical and symptomatic improvement following carbimazole therapy. The presenting symptoms of anorexia and weight loss suggestive of a gastric neoplasm are not infrequently seen in elderly persons with thyrotoxicosis (Trotter, 1962). The absence of a goitre is also noteworthy since thyrotoxicosis without detectable thyroid enlargement is seldom seen in women (Trotter, 1962).

The clinical picture and raised fasting blood pyruvate levels, together with the improvement following intravenous thiamine, substantiate the diagnosis of Wernicke's encephalopathy. We believe that this was probably precipitated for three reasons:

(1) The decreased dietary intake of thiamine due to anorexia.

(2) Increased utilization of thiamine due to thyrotoxicosis.

(3) Possible malabsorption of thiamine. Apart from the glucose tolerance curve and impaired xylose excretion, objective evidence of this was lacking in this case. On theoretical grounds, however, one might postulate the increased intestinal transit time due to thyrotoxicosis and possibly an autonomic neuropathy of the gut such as is known to occur in animals with experimental thiamine deficiency (Rowlands \& Browning 1928).

\section{Acknowledgments}

We are grateful to Dr C. E. C. \Wells for permission te publish this case and to Professor $\mathbf{H}$. Scarborough for hiא, criticism of the report.

\section{References}

Campbell, A.C.P. \& Russell, W.R. (1941) Wernicke' encephalopathy. The clinical features and probable relationship to Vit: B. deficiency. Quart. J. Med. N.s. 10, 41.

GAYET, C.J.A. (1875) Affection encephalique (encephalite diffuse probable) localisee aux etaques des pedoncles cerebraux et aux couches optiques. Arch. Physiol. norm. path. 2 Ser. 2, 341.

Jolliffe, N., Wortis, H. \& Fein, H.D. (1941) The Wernicke Syndrome. Arch. Neurol. Psychiat. 46, 569.

Rowlands, M.J. \& BrownING, E. (1928) The relation of Vit: B to atony of the stomach. Lancet, i, 180.

Trotter, W.R. (1962) Diseases of the Thyroid. Blackwell Scientific Publications, Oxford.

WeChSLER, I. (1932) Communication to the Neurological Section of the New York Academy of Medicine. Quoted by BENDER, L. \& SCHILDER, C. (1933) Encephalopathia alcoholica: polioencephalitis haemorrhogica superior of Wernicke. Arch. Neurol. Psychiat. 29, 990.

WeRnicke, C. (1881) Die acute, haemorrhagiasche Polioencephalitis superior. Lehrbuch der Gehirnkrun kheiten fur Aerzte und Studierende, Vol. 2, p. 229. Kassel und Berlin. 